\title{
Post-Harvest Behavior of Different Lettuce Cultivars and their Cut Form sunder Different Storage Conditions
}

\author{
Supriya S. Patil, Sangram S. Dhumal*, Deepak R. Patgaonkar, Vishnu K. Garande, \\ Manpreet Kaur
}

Department of Horticulture, College of Agriculture, Kolhapur, (MPKV Rahuri), India

\begin{abstract}
${ }^{1}$ Supriya S, Patil, Sr. M.Sc. Student, Department of Horticulture, College of Agriculture, Kolhapur-416004, Maharashtra, India. ${ }^{2}$ Dr. Sangram S. Dhumal, Assistant Professor of Horticulture, College of Agriculture, Kolhapur-416004, Maharashtra, India. ${ }^{3}$ Deepak R. Patgaonkar, Assistant Professor of Horticulture, Department of Horticulture, College of Agriculture, Kolhapur416004, Maharashtra, India

${ }^{4}$ Vishnu K. Garande, Associate Professor of Horticulture, Department of Horticulture, College of Agriculture, Kolhapur-416004, Maharashtra, India.

${ }^{5}$ Manpreet Kaur, Sr. M.Sc. Student, Department of Horticulture, College of Agriculture, Kolhapur-416004, Maharashtra, India.
\end{abstract}

Abstract-The four leaf type lettuce cultivars i.e. GKL-1, GKL-2, GKL-3 and Chinese Yellow were evaluated for postharvest behavior during storage. The harvested fresh leaves of different lettuce cultivars were processed into two forms i.e. whole leaf form and cut form $(5 \times 3 \mathrm{~cm})$ and were stored at two storage conditions i.e. refrigerated storage $\left(5 \pm l^{\circ} \mathrm{C}\right)$ and $\mathrm{ZECC}\left(9-15^{\circ} \mathrm{C}\right)$. Results revealed that whole leaf form of lettuce cultivars stored in refrigerated condition recorded minimum changes in physico-chemical parameters. With the advancement of storage period decrease in per cent moisture, ascorbic acid and polyphenol content was observed in all treatments irrespective of cultivars, forms and storage conditions. The maximum per cent browning and decay was observed in ZECC storage which was minimum in refrigerated storage.The whole leaf form of lettuce cultivar Chinese Yellow recorded shelf life of 15 days when stored at refrigerated storage $\left(5 \pm l^{\circ} C\right)$, whereas other cultivars (GKL-1, GKL-2 and GKL-3) recorded shelf life of 12 days. Whole leaf form of Lettuce cultivars stored in ZECC condition recorded shelf life upto 6 days while freshcut lettuce recorded shelf life of 3 days in ZECC. Fresh-cut lettuce recorded accelerated physiological loss in weight, moisture loss with increase in browning and decay percentage. Decrease in per cent moisture, ascorbic acid and polyphenol content with increase in physiological loss in weight was recorded in all treatments over the period of storage irrespective of cultivars, forms and storage conditions. The whole leaf form of lettuce cultivar Chinese
Yellow recorded minimum changes in physico-chemical parameters and controlled enzymatic browning which maintained sensorial marketable quality and enhanced acceptability of lettuce leaves up to 15 days when stored at refrigerated storage $\left(5 \pm l^{\circ} \mathrm{C}\right)$.

Keywords-Lettuce Cultivars, ZECC, GKL-1, GKL-2, GKL-3.

\section{INTRODUCTION}

Lettuce (Lactuca sativa), is an important and fast emerging salad crop of Asteraceae family, originated in Asia and extensively grown in European countries, USA, Mexico, Chile, Argentina, Brazil, Peru, China, Japan and Australia. Among the three main type viz., leaf, head and cos or romaine (Bradleyet al., 2009), leaf lettuce is commonly grown in India. Fresh-cut lettuce, which represents more than $80 \%$ of the total production of fresh-cut produce, has been one of the more highly requested commodities by fast food services and salad bars (Beltran, 2005). It became popular due to its crispy texture, attractive green leaves, neutral taste and green aroma (Ricoet al., 2007) and widely known as the "queen of the salad plants" (Martin and Ruth 1975).Among the modern types of lettuce are two crisphead forms viz., iceberg which forms a large firm head and Batavia which is slightly softer and smaller than iceberg are popular in western countries. Romaine lettuce has long leaves in a loaf-shaped head. Butterhead lettuce is quite small with oily soft textured leaves. Red and green leaf 
lettuce form no head and have leaves with a variety of shapes. Less commonly found are the Latin type, which looks like a small romaine, and the aforementioned stem and oil seed lettuce. Iceberg lettuce is composed of soft leaves that contain large amounts of moisture (more than 95\%), and is not only improves the appearance of the food, but also increases the nutritional value of mixed salads (Kanget al., 2007). It is predominantly used for prepared salads, but other types of lettuce are now being used in salad mixes. Information on the postharvest behavior of other lettuces is lacking, especially with regard to their quality in salad packs (Lopez-Galvez et al., 1996)

The demand for fresh-cut fruits and vegetables has been increasing over the past 10 years owing to the convenience of fresh-cut fruits and vegetables as ready-to-eat products coupled with the health benefits associated with their consumption (Rimmet al., 1996). Packaged salad-cut lettuce for food service and salad mixes is an increasingly important component of the lettuce industry (Glaser et al., 2001). However, it is well known that minimally processed fruits and vegetables are generally more perishable than the original raw materials (Rojas-Grauet al., 2008). The postharvest losses estimated in lettuce are in range of 20$30 \%$ (Serratoet al., 2014) due to mechanical stress during processing that results in cellular delocalization of enzymes and their substrates leading to biochemical deteriorations such as enzymatic browning, off-flavor and texture browning (Varoquaux, 1991).

Fresh-cut lettuce is highly perishable with a shelf life of 2-3 days due to high water content and running metabolic activities. Shelf life and the visual quality of salad-cut lettuce can be affected by the production environment, vegetative maturity, storage temperature, choice of cultivar and its cut forms used. (Chiesaet al., 2003; Watada and Qi, 1999 and Couture et al., 1993) Cold storage and modifiedatmosphere (MA) packaging are used to extend its shelf life. Postharvest losses in relation to quality and quantity of food are a major problem all over the world, which can be controlled by optimal storage time and temperature (Khanet al., 2012; Lamikanra, 2002). Quality maintenance currently relies chiefly on the selection of suitable cultivars and the maintenance of low temperatures (optimum $1^{\circ} \mathrm{C}$ ) during storage, distribution and retail (Ahvenainen, 2000). Postharvest storage time and temperature can have an influence on ascorbic acid content, antioxidant activity and total phenolic content (Lamikanra, 2002). The lettuce postharvest processing operation has several challenges due to large variations in respiration rate from different cultivars, large seasonal variation and postharvest storage duration prior to processing. Given the importance of the market, lettuce cultivars, breeding lines and populations should be selected for increased shelf life in cold storage environments. To implement this practice, effective evaluation method and knowledge of the genetic variation within lettuce for shelf life is needed. Therefore, the present research work is proposed to determine and study the postharvest behavior of different lettuce cultivars and their cut forms at different storage temperatures.

\section{MATERIALS AND METHODS}

The present investigation on evaluation of lettuce cultivars and their forms for postharvest behavior during storage was conducted in the Post-harvest Technology laboratory of Horticulture Section, College of Agriculture, Kolhapur from July to August, 2015.The lettuce crop selected for investigation was of leaf type. The healthy, fresh photosynthetically active lettuce leaves of optimal maturity of four cultivars viz., GKL-1, GKL-2, GKL-3 and Chinese Yellow were collected from Instructional-cum-research farm of Horticulture section, College of Agriculture, Kolhapur. They were prepared for storage on the same day. The lettuce leaves of different cultivars were sorted for integrity, color and size uniformity, and lack of defects. Outer leaves were discarded to reduce natural variability among samples and only photosynthetic leaves (green leaves) were included in the samples. Lettuce leaves were washed in running tap water for $4 \mathrm{~min}$ at room temperature $\left(20^{\circ} \mathrm{C}\right)$ in a ratio of one part of lettuce for 10 parts of water. Excess water was drained by using sterilized stainless steel sieve. Intact leaves were used for whole lettuce form while the cut form of fresh-cut lettuce was prepared by cutting leaves into $5 \times 3 \mathrm{~cm}$ size and by shredding into $1 \times 0.5 \mathrm{~cm}$ with sharpened stainless steel knife sterilized in alcohol at $13^{\circ} \mathrm{C}$ temperature. Food grade sodium hypochlorite solution $150 \mathrm{mg} \mathrm{L}^{-1}$ was used for dipping of lettuce for $15 \mathrm{~min}$. Processed lettuce leaves weighing $250 \mathrm{~g}$ were filled in consumer polypropylene food grade plastic bags of $25 \times 20 \mathrm{~cm}$ size and 150 gauge thick with low permeability for moisture. A closed glass chamber was prepared. The gas cylinder was fixed to inlets. The internal gas flow was regulated and weighed lettuce was filled in bags and were flushed with $100 \%$ nitrogen gas. Storage studies were conducted at different conditions viz; refrigerated storage at $5 \pm 1^{\circ} \mathrm{C}, \mathrm{ZECC}$ at $9-15^{\circ} \mathrm{C}$ and ambient storage at $25-30^{\circ} \mathrm{C}$. Pilot trials were conducted from January to February 2015 for different lettuce cultivars by applying the storage environment and cut forms revealed that shelf life of all forms of lettuce at ambient storage and of shredded lettuce at all temperatures was upto 2-3 days only. Hence in 
final trial, conducted from July to August 2015, ambient storage treatment and shredded form of lettuce treatment were deleted. Samples were evaluated every 3 days interval.

\section{Physico-chemical analysis}

The percent moisture was determined by drying known weight of sample into hot air oven (Metalab) at $60^{\circ} \mathrm{C}$ for 24 hours for a constant known weight. (A.O.A.C. 2010).Weight loss was estimated based on the fresh produce weight and the significant change in physiological weight loss of lettuce leaves during storage was determined on percentage basis. In all samplings the fresh weight was measured by an electronic scale of $\pm 0.01 \mathrm{~g}$ accuracy and reduction in weight over initial weight in percentage was calculated according to Akhteret al. (2013). Ascorbic acid was estimated as per the modified visual titration procedure of A.O.A.C (2010) and calculated in terms of $\mathrm{mg}$ per $100 \mathrm{~g}$ of fresh-cut leaves.The Phenol content in lettuce leaves was determined by colorimetric method using Folin-Denis reagent (A.O.A.C., 2005). The optical density was read at $760 \mathrm{~nm}$ on spectronic20 and phenols were expressed as $\mathrm{mg}$ of gallic acid equivalents per $100 \mathrm{~g} \mathrm{FW}$ of sample.The lettuce surface browning was determined visually on weight basis of lettuce and expressed in percentage as stated by Khumjinget al. (2011).The percent decay of lettuce leaves during storage was calculated based on visual inspection of each leaf for infection. Percent decay was calculated according to Gihan (2010) on weight basis.

\section{RESULT AND DISCUSSION}

As regards ZECC storage conditions, considering the condition of lettuce samples, the data was recorded up to 6 days only while in case of fresh-cut form of lettuce, the data was recorded only for 9 days. Thereafter both the treatments were terminated. All the lettuce cultivars except Chinese Yellow, had the marketable acceptability up to 12 days only. In respect of the lettuce cultivar Chinese Yellow observations were recorded upto 15 days.

\section{Percent moisture and physiological loss in weight (\%)}

Weight loss is a very important factor as it is associated with economic issues and generally weight loss more than 5\% reduces the market value of vegetables (Brown and Bourne, 2002). Water loss in vegetables is determined by many factors, the most important of which is the resistance exerted by the outer periderm or cuticle movement of water vapour due to transpiration as reported by Ben-Yehoshua(1987). However cutting of produce results in resistance reduction of these barriers to transpiration. Cut products are highly susceptible to physiological weight loss because internal tissues are exposed to atmospheric conditions than the intact products. In present study, the per cent moisture of lettuce leaves was significantly influenced by different cultivars, cut forms, storage conditions and their interactions. Maximum per cent moisture $\left(90.15 \%\right.$ on $15^{\text {th }}$ day) and minimum physiological loss in weight $\left(0.99 \%\right.$ on $15^{\text {th }}$ day $)$ was recorded in treatment $\mathrm{V}_{4} \mathrm{~T}_{1} \mathrm{~F}_{1}$ (whole leaf form of lettuce cultivar Chinese yellow stored in refrigerated storage). The low storage conditions $\left(5 \pm 1^{\circ} \mathrm{C}\right)$ and high relative humidity conditions maintained throughout the storage period along with the lowest cutting grade i.e. whole leaf could be the possible reasons of maintenance of per cent moisture upto 15 days. However, slight moisture losses were recorded during the storage this might be due to respiratory activities, induction of new enzymes and membrane degradation of lettuce leaves as reported by Mattoset al. (2013) in fresh-cut lettuce; Moretti et al. (2007) in baby carrots.

The physiological loss in weight increased with decrease in moisture content of fresh lettuce leaves. The loss in per cent moisture resulted in reduction of fresh weight accompanied by the loss of freshness, appearance and texture as observed by Manolopoulou and Varzakas (2011). Evaporation, transpiration and respiration of fresh-cut leaves after harvest and imbalance of vapor pressure in the product tissues and the air inside the package lead towards weight loss over time as reported by Moreira et al. (2006). In addition to modified atmosphere packaging ( $\mathrm{N}_{2}$ flushing), use of polypropylene bag and low temperature storage condition were the most important factors in preventing water loss. Similar findings were reported by Ansahet al. (2015) in fresh-cut iceberg lettuce, Sereaetal. (2014) in fresh lettuce leaves and by Manolopoulou et al. (2010) in fresh-cut Romaine lettuce. For the samples stored under refrigerated conditions @ $5 \pm 1^{\circ} \mathrm{C}$, dehydration was not a major problem but it affected the samples stored in ZECC (Table 1 and Fig. 2). Only slight changes in physiological loss in weight were found during the entire period of storage for all treatments as observed by Kang et al. (2007) in fresh-cut lettuce. The weight loss increased with the increase in temperature ofstorage conditions throughout the storage period, the findings of present study were in favour of Moreira et al. (2006) in lettuce leaves and Kim et al. (2004) in salad savoy. The temperature and relative humidity must be controlled forpreventing the moisture loss of vegetables as reported by Thompson (2004).The fresh-cut iceberg lettuce was highly susceptible to dehydration as observed by Kanget al. (2007). Minimum cutting of tissue and low temperature storage maintained the weight for maximum period, the similar results were also reported byRazaliet al. (2004) in minimally 
processed long beans and by Tuncayand Kusaksiz (2003) in cut leeks.

\section{Browning percentage}

Polyphenol oxidase is an enzyme implicated in the enzymatic browning process. Increase in polyphenol activity during storage contribute to browning which was measured on per cent basis of fresh weight of lettuce in this study as reported by Martin-Diana et al. (2005) in salad-cut iceberg lettuce and by Loaiza-Velarde et al. (2001) in fresh-cut celery petiole. Browning is the main cause of quality loss in minimally processed lettuce. Oxygen $\left(\mathrm{O}_{2}\right)$ is necessary substrate in the enzymatic browning as observed by Sandhya (2010) on fresh produce and by Jacxsenset al. (2001) in fresh-cut lettuce. Slow increase in browning per cent (Table 2 and Fig. 2) in lettuce leaves might be due to inhibition of necessary substrate required for browning i.e nitrogen flushing as reported by Mattoset al. 2013 in fresh-cut crisphead lettuce.

Lettuce cultivar Chinese Yellow recorded minimum per cent browning $\left(4.17 \%\right.$ on $15^{\text {th }}$ day) as compared to other cultivars. Differences in browning potential among the lettuce cultivars was observed, it might be due to variations in phenolic metabolism as reported by Hyodoet al. (1978) in various lettuce cultivars. The maximum percentage of browning ( $3.93 \%$ on $9^{\text {th }}$ day) was observed in cut form of lettuce this might be due to cutting of leaves which increase polyphenol oxidase activity due to provoking of tissue wounding which in turn has might increased respiration rate and ethylene emission as well as increase in phenylalanine ammonia lyase activity and soluble phenolic content stimulating browning, the results are in conformity with Castaneret al. (1999) in baby and romaine lettuce, Mattilaet al. (1995) in minimally processed vegetables, Mateoset al. (1993) in lettuce and Ke and Saltveit(1989) in iceberg lettuce. In photosynthetic tissue, soluble brown pigments slowly increased during storage, showing the similar trend in all lettuce cultivars. This suggests that the photosynthetic tissue also developed browning although other natural pigmentssuch as chlorophyll masked the brown discoloration. In all the treatments browning percentage increased with increase in temperature during storage and was minimum at low temperature storage (Refrigerated storage @ $5 \pm 1^{\circ} \mathrm{C}$ ). This might be due to lowering down the metabolic activities due to low temperature. These results are in conformity with the results reported by Grzegorzewska (2007) in fresh-cut crisp lettuce and Castaneret al. (1999) in baby and romaine lettuce.

Decay percent
Increasing trend for per cent decay was observed throughout the storage period as summarized in Table 2 and Fig. 2. Among the cut forms, whole leaf formof lettuce reported minimum decay $\left(1.89 \%\right.$ on $9^{\text {th }}$ day) than cut form $(2.73 \%$ on $9^{\text {th }}$ day) of lettuce as observed by Mattilaet al. (1995). The decay percentage increased was found to be increased with the increase in storage temperature as reported by Grzegorzewska (2007) and by Kim et al. (2004). Increase in per cent decay in cut form might be due to the increase in wounded tissue surface that cause condensation in the lettuce bags which created aqueous focuses for the development of microorganisms which leads to decay. The low levels of oxygen favours fermentation processes which might cause the formation of theacetaldehyde and off flavour compounds which may cause decay as reported by Kays and Kapoor, 2000 in minimally processed fruits and vegetables. Maximumper cent decay $\left(2.46 \%\right.$ on $6^{\text {th }}$ day) was observed for samples stored in ZECC due to higher temperature storage condition and higher humidity. The $100 \%$ nitrogen flushing in lettuce packages and low temperature storage $\left(5 \pm 1^{\circ} \mathrm{C}\right)$ was helpful in preventing the decay percentage $\left(1.50 \%\right.$ on $6^{\text {th }}$ day) as reported by Sereaet al., (2014) and Luoet al., (2010) in minimally processed iceberg and Romaine lettuce.

\section{Ascorbic acid (mg/100g)}

Ascorbic acid is a cofactor in numerous enzymatic reactions and an important nutritional component of fruit and vegetables. It is very labile and its preservation is of crucial importance to the human diet (Ezell and Wilcox, 1959). Ascorbic acid is the predominant form of vitamin-C in freshcut iceberg lettuce, representing 55-65\% of the total vitamin $\mathrm{C}$ content. The initial ascorbic acid content of lettuce leaves ranged between 11.61 to $11.82 \mathrm{mg} / 100 \mathrm{~g}$. The results are in conformity with Moreiraet al. (2006).

Maximum ascorbic acid $\left(11.24 \mathrm{mg} / 100 \mathrm{~g}\right.$ on $15^{\text {th }}$ day) was observed in whole leaf form of Chinese Yellow cultivar stored in refrigerated storage throughout the storage period. However, with advancement of storage period decrease in ascorbic acid content was observed (Table 3 and Fig. 3) in all treatments. These results are in conformity with Spinardiet al. (2010) in baby lettuce. Maximum loss of ascorbic acid was observed in cut form of lettuce cultivars stored in ZECC conditions $\left(11.25 \mathrm{mg} / 100 \mathrm{~g}\right.$ on $6^{\text {th }}$ day) this might be due to the affinity of ascorbic acid towards water, its thermal destruction, increase surface area and wounding and enzymatic oxidation during storage as reported by Selmon (1994). Also increase in storage time and respiration might has played important role in ascorbic acid reduction as reported by Sharmaet al. (2011) in minimally processed 
vegetables, Spinardiet al. (2010) in spinach and lettuce baby leaf, Ferrante et al. (2009) in lambs lettuce, Myojinet al. (2008) in bellpepper andLamikaranaet al. (2002) in fresh-cut fruits and vegetables. The stability of ascorbic acid is generally enforced by maintaining low temperature duringstorage (Fennema, 1996). Loss in ascorbic acid is attributed to both, temperature and water loss (Kader, 2002). The rate of degradation of ascorbic acid in lettuce leaves stored at abusive temperature storage conditions (ZECC and ambient storage) $\left(11.25 \mathrm{mg} / 100 \mathrm{~g}\right.$ on $6^{\text {th }}$ day) was faster than at low temperature storage condition $\left(0^{\circ} \mathrm{C}\right)(11.41 \mathrm{mg} / 100 \mathrm{~g}$ on $6^{\text {th }}$ day) as observed by Moreiraet al. (2006).

The whole leaf form of lettuce recorded maximum ascorbic acid content $\left(11.24 \mathrm{mg} / 100 \mathrm{~g}\right.$ on $15^{\text {th }}$ day) at the end of storage these might be due to the photosynthetic activity and absence of wound which might have decreased respiration rate and ethylene formation. Cutting of vegetables leads to decrease in ascorbic acid at higher rate than whole intact leaves which might be due to increase in ethylene production due to cut made in fresh-cut products and this ethylene could stimulate other physiological processes such as the degradation of vitamin $\mathrm{C}$ etc. as reported by Cocettaet al. (2014) in fresh-cut baby spinach and by Kader (1985) in vegetables. Gradual decrease in ascorbic acid content observed in this experiment could be connected with increase in breathing intensity after minimal processing. The organic acids together with another compounds take part in the breathing reactions, as a result the total content of acids decreases and $\mathrm{pH}$ value increase as reported by SolivaFortuny et al. (2003) and Luo et al. (2010) in lettuce.

\section{Polyphenol (mg/100g)}

Initial polyphenolic content $(\mathrm{mg} / 100 \mathrm{~g})$ of lettuce leaves ranged from 8.6 to $8.7 \mathrm{mg} / 100 \mathrm{~g}$ (Table 3 and Fig. 3). Scarce changes were observed in polyphenol content over the storage period. Polyphenol content showed a decreasing trend with time. This could be due to the reduced plant biochemical processes, such as production of ethylene, respiration, enzymatic activities as a result of low oxygen environment and low storage temperature. However, the slight reduction in polyphenols might be due to the use of polyphenols as substrate for the polyphenol enzyme and the conversion between free and bound phenolic substances as reported by Ferranteet al. (2009) in lambs lettuce.

The main interest of polyphenol analysis was to evaluate the possible effect of cultivars, cut forms and storage conditions of lettuce leaves on the polyphenolic content which is responsible for antioxidant activity. The phenolic compounds accumulate in lettuce leaves, and are associated with subsequent tissue browning. Polyphenols decreased much more slowly in refrigerated storage $(8.65 \mathrm{mg} / 100 \mathrm{~g}$ on $6^{\text {th }}$ day) than ZECC $\left(9-15^{\circ} \mathrm{C}\right)\left(8.62 \mathrm{mg} / 100\right.$ on $6^{\text {th }}$ day $)$. This might be due to low temperature which slowed down plant metabolic processes, such as respiration, ethylene production and enzyme activity. The decrease in polyphenols was maximum in fresh-cut lettuce $\left(8.61 \mathrm{mg} / 100 \mathrm{~g}\right.$ on $9^{\text {th }}$ day) than whole leaf form $\left(8.64 \mathrm{mg} / 100 \mathrm{~g}\right.$ on $9^{\text {th }}$ day). The polyphenol oxidase and polyphenols are found in different organelles of plant cells. When tissue is damaged, they meet and react with each other. As a result the polyphenols decrease at a rapid rate in cut tissues than intact leaves. The results of present study are in close conformity with the results obtained by Altunkaya andGokmen (2007) in lettuce.

\section{SUMMARY AND CONCLUSIONS}

The data on initial analysis of cultivars revealed that Chinese Yellow cultivar had highest level of ascorbic acid (11.82 $\mathrm{mg} / 100 \mathrm{~g})$, phenols $(8.72 \mathrm{mg} / 100 \mathrm{~g})$ and moisture (92.67\%) followed by GKL-3 and GKL-2 and lowest content of all parameters was recorded in GKL-1. Whole leaf form of Chinese Yellow cultivar recorded shelf life of 15 days at refrigerated storage and 6 days at ZECC while whole leaf form of GKL-1, GKL-2 and GKL-3 recorded shelf life of 12 days at refrigerated storage condition. Cut leaf form of lettuce cultivars recorded shelf-life of 9 days at refrigerated storage and 3 days at ZECC. The minimum changes in physico-chemical parameters of lettuce cultivars were recorded under refrigerated storage as compared to ZECC storage. Decrease in per cent moisture, ascorbic acid and polyphenol content was observed in treatments irrespective of cultivars, forms and storage conditions. The maximum per cent browning and decay was observed in cut form of lettuce stored in ZECC storage. The lettuce cultivar Chinese Yellow recorded minimum changes in physico-chemical parameters throughout the storage period. In respect of interaction effect cut form of lettuce cultivar GKL-1 stored in $\mathrm{ZECC}\left(\mathrm{V}_{1} \mathrm{~T}_{2} \mathrm{~F}_{2}\right)$ registered maximum changes in regards of physico-chemical parameters while maximum retention was recorded by whole leaf form of Chinese Yellow cultivar stored in refrigerated storage $\left(\mathrm{V}_{4} \mathrm{~T}_{1} \mathrm{~F}_{1}\right)$.

\section{REFERENCES}

[1] Ahvenainen, R. 2000. Minimal processing of fresh produce. In: Minimally Processed Fruits and Vegetables: Fundamental Aspects and Applications. S. M. Alzamora, A. Lopez-Malo, M. S. Tapia, (Eds). Aspen Publishers, Gaithersburg, MD. pp. 277-290.

[2] Akhter, F., Islam, M., Khatun, A., Munshi, M., Hossain, M., Hoque, M. and Huque, R. 2013. 
Biochemical composition and effects of radiation on sensory, biochemical and physiological quality of fresh spinach (Spinaciaoleracea L.). Int. J. Biosciences. 3: 25-34.

[3] Altunkaya, A. and Gokmen, V. 2007. Effect of various inhibitors on enzymatic browning, antioxidant activity and total phenol content of fresh lettuce (Lactuca sativa). Food Chem. 107: 1173-1179.

[4] Ansah, A. F., Amodio, L. M. and Colelli, G. 2015. Evaluation of the impact of nitrous oxide use on quality and shelf life of packaged fresh-cut iceberg lettuce and wild rocket. Chemical Eng. Transactions. 44: 319-324.

[5] AOAC., 2005. International Official Methods of Analysis. $18^{\text {th }}$ Edn., Association of Official Analytical Chemists, Washington, DC., U.

[6] AOAC., 2010. International Official Methods of Analysis. $18^{\text {th }}$ Edn., Association of Official Analytical Chemists, Washington, DC., U.

[7] Beltran, D., Selma, M. V., Marin, A. and Gil, M. I. 2005. Ozonated water extends the shelf life of fresh-cut lettuce. J. Agric. Food Chem. 53: 5654-5663.

[8] Ben-Yehoshua, S. 1987. Transpiration water stress and gas exchange. In: Postharvest Physiology of Vegetables, ed. J. Weichmann, Marcel Dekker, Inc., New York. pp. 113-170.

[9] Bradley, F. M., Barbara, W. E. and Deborah, L. M. 2009. The Organic Gardener's Handbook of Natural Pest and Disease Control:A Complete Guide to Maintaining a Healthy Garden and Yard the EarthFriendly Way. Rodale. ISBN-13: 978-1-60529-677-7.

[10] Brown, S. K. and Bourne, M. C. 2002. Assessment of components of fruit firmness in selected sweet cherry genotypes. HortScience. 23: 902-904.

[11] Castaner, M., Gill, M. I., Ruiz, M. V., and Artes, F. 1999. Browning susceptibility of minimally processed Baby and Romaine lettuces. Eur. Food Res. Technol. 209: 52-56.

[12] Cheisa, A., Frezza, D., Fraschina, A., Trincheros, G., Moccia, S. and Leon, A. 2003. Pre-harvest factors and fresh-cut vegetable quality. Acta Hort. 604: 153-159.

[13] Cocetta, G., Baldassarre, V., Spinardi, A. and Ferrante, A. 2014. Effect of cutting on ascorbic acid oxidation and recycling in fresh-cut baby spinach (Spinaciaoleracea L.) leaves. Postharvest Biol. Technol. 88: 8-16.

[14] Couture, R., Cantwell, M. I., Ke, D. and Saltveit, Jr. M. E. 1993. Physiological attributes related to quality attributes and storage life of minimally processed lettuce. HortScience. 28(7): 723-725.
[15] Ezell, B. D. and Wilcox, M. S. 1959. Loss of vitamin C in fresh vegetables as related to wilting and temperature. J. Agric. Food Chem. 7: 507-509.

[16]Fennema, R. O. 1996. Food Chemistry. $3^{\text {rd }}$ Edition. Marcel Dekker, Inc. New York. ISBN 10: 0824793463.

[17] Ferrante, A., Martinetti, L. and Maggiore, T. 2009. Biochemical changes in cut vs. intact lamb's lettuce (Valerianellaolitoria) leaves during storage. Int. J. Food Sci. Technol. 44(5): 1050-1056.

[18] Gihan, G. A. 2010. Effect of gamma radiation on microbial load and chemical constituents of banana fruits stored under different temperatures. Res. J. Agril. Biol. Sci. 6(4): 431-442.

[19] Glaser, L. K., Thompson, G. D. and Handy, C. R. 2001. Recent changes in marketing and trade practices in the U.S. lettuce and fresh-cut vegetables industries. Agri. Info. Bull. No. 767.

[20] Grzegorzewska, M. 2007. The influence of postharvest treatment and short term storage on quality and durability of fresh-cut Crisp lettuce (Lactuca sativa L. var. Capitata L.). Veg. Crops Res. Bulletin. 67: 137147.

[21] Hyodo, H., Kuroda, H. and Yang, S. F. 1978. Induction of phenylalanine ammonia lyase and increase in phenolics in lettuce leaves in relation to the development of russet spotting caused by ethylene. Plant physiol. 62: 31-35.

[22] Jacxsens, L., Devlieghere, F., and Debevere, J. 2001. Effect of high oxygen modified atmosphere packaging on microbial growth and sensorial qualities of fresh-cut produce. Int. J. Food Microbiol. 71: 197-210.

[23] Kader, A. A. 1985. An overview of the physiological and biochemical basis of CA effects on fresh horticultural crops. In: Blankenship, S. (Ed.) Controlled Atmospheres for Storage and Transport of Perishable Agricultural Commodities. Proc. $4^{\text {th }}$ Natl. Controlled Atmosphere Res. Conf., Raleigh, North Carolina. Hort. Rept. No. 126, Dept. Hort. Sci., North Carolina State Univ., Raleigh, NC, USA. pp. 1-9.

[24] Kader, A. A. 2002. Postharvest technology of horticultural crops, third edition. University of California, Agriculture and Natural Resources, Publication No. 3311. pp. 535.

[25] Kang, S. C., Kim, M. J. and Choi, U. K. 2007. Shelflife extension of fresh-cut lettuce (Lactuca sativa $\mathrm{L}$ ) by different antimicrobial films. J. Microbiol. Biotechnol. 17(8): 1284-1290.

[26] Kang, S. C., Kim, M. J. and Choi, U. K. 2007. Shelflife extension of fresh-cut lettuce (Lactuca sativa $\mathrm{L}$ ) by 
different antimicrobial films. J. Microbiol. Biotechnol. 17(8): 1284-1290.

[27] Kays, C. and Kapoor, H. C. 2000. Minimal processing of fruits and vegetables. Indian Food Packer. 156-164.

[28] Ke, D. and Saltveit, M. E. 1989. Wound induced ethylene production, phenolic metabolism and susceptibility to russet spotting in iceberg lettuce. Physiol. Plant. 76: 412-418.

[29] Khan, A. S., Ahmad, N., Malik, A. U. and Amjad, M. 2012. Cold storage influences the postharvest pericarp browning and quality of litchi. Int. J. Agric. Biol. 14(3): 389-394.

[30] Khumjing, C., Chutichudet, B., Chutichudet, P. and Boontiang, K. 2011. Effects of Different Calcium Applications for Controlling Browning Appearance in Lettuce. Int. J. Agril. Res. 6: 238-254.

[31] Kim, J. G., Luo, Y. and Gross, K. C. 2004. Quality and shelf-life of salad savoy under different storage temperatures. J. Kor. Soc. Hort. Sci. 45(6): 307-311.

[32] Lamikanra, O. 2002. Preface. In: O. Lamikanra (Ed.), Fresh-cut fruits and vegetables. Science, Technology and Market CRC Press, Boca Raton, Florida. pp. 99.

[33] Loaiza-Velarde, J. G., and Saltveit, M. E. 2001. Heat shocks applied either before or after wounding reduce browning of lettuce leaf tissue. J. American Soc. Hort. Sci. 126: 227-234.

[34] Lopez-Galvez, G., Saltveit, M. and Cantwell, M. 1996. Wound-induced phenylalanine ammonia lyse activity: Factors affecting its induction and correlation with the quality of minimally processed lettuces. Postharvest Biol. Technol. 9: 223-233.

[35]Luo, Y., He, Q. and McEvoy J. L. 2010. Effect of storage temperature and duration on the behavior of Escherichia coli O157:H7 on packaged fresh-cut salad containing Romaine and Iceberg lettuce. J. Food Sci. 75(7): M 390-397.

[36]Luo, Y., He, Q. and McEvoy J. L. 2010. Effect of storage temperature and duration on the behavior of Escherichia coli O157:H7 on packaged fresh-cut salad containing Romaine and Iceberg lettuce. J. Food Sci. 75(7): M 390-397.

[37] Manolopoulou, E. and Varzakas, T. 2011. Effect of storage conditions on the sensory quality, colour and texture of fresh-cut minimally processed cabbage with the addition of ascorbic acid, citric acid and calcium chloride. Food Nutri. Sci. 2: 956-963.

[38] Manolopoulou, H., Lambrinos, G. R., Chatzis, E., Xanthopoulos, G. and Aravantinos, E. 2010. Effect of temperature and modified atmosphere packaging on storage quality of fresh-cut Romaine lettuce. J. Food Quality. 33: 317-336.

[39] Martin, F. W., and Ruth, M. R. 1975. Edible Leaves of the Tropics. Mayaguez, Puerto Rico: Agency for International Development, Department of State, and Department of Agriculture-Agricultural Research Service.

[40] Martin-Diana, A. B., Rico, D., Barry-Ryan, C., Frias, J. M., Mulcahy, J. and Henhen, G. T. M. 2005. Calcium lactate washing treatments for salad-cut iceberg lettuce: Effect of temperature and concentration on quality retention parameters. Food Res. Int. 38(7): 729-740.

[41] Mateos, M., Ke, D., Kader, A. and Cantwell, M. 1993. Differential responses of intact and minimally processed lettuce to high carbon dioxide atmospheres. Acta Hort. 343: 171-174.

[42] Mattila, M., Ahvenainen, R., Hurme, E. and Hyvtinen, L. 1995. Respiration Rates of Some Minimally Processed Vegetables in Proceedings of Workshop on Systems and Operations for Post-harvest Quality (De Baerdemaeker, J. et al., eds), pp. 135-145.

[43] Mattos, L. M., Moretti, C. L. and Silva, E. Y. Y. 2013. Effects of modified atmosphere packaging on quality attributes and physiological responses of fresh-cut crisphead lettuce. J. Food. 11(4): 392-397.

[44] Moreira, M. del R., Ponceb, A. G., Vallea, C. E., Ansorenab, R., and Rourab, S. I. 2006. Effects of abusive temperatures on the postharvest quality of lettuce leaves: ascorbic acid loss and microbial growth.J. App. Hort. 8(2): 109-113.

[45] Moretti, C. L., Mattos, L. M., Machado, C. M. M. and Kluge, R. A. 2007. Physiological and qulaity attributes associated with different centrifugation times of baby carrots. HorticulturaBrasiliera. 25: 557-561.

[46] Myojin, C., Yamacuchi, T., Takamura, H. and Matoba T., 2008. Changes in radial scavenging activity of shredded vegetables during storage. Food Sci. Technol. Res. 14: 198-204.

[47] Razali, M., Habsah, M. and Che Omar, D. 2004. Effect of different forms of cutting on quality of minimally processed long bean (Vignasesquipedalis L.) during storage. J. Trop. Agric. Food Sci. 32(1): 45-56.

[48] Rico, D., Martin-Diana, A. B., Barat, J. M. and BarryRyan, C. 2007. Extending and measuring the quality of fresh-cut fruit and vegetables: a review. Trends Food Sci. Technol. 18: 373-386.

[49] Rimm, E. B., Katan, M. B., Ascherio, A., Stampher, M. J. and Willett, W. C. 1996. Relation between intake of 
flavonoids and risk of coronary heart disease in male health profssionals. Ann. Intern. Med. 125: 384-389.

[50] Rojas-Grau, M. A., Soliva, R. and Martin-Belloso, O. 2008. Effect of natural antibrowning agents on colour and related enzymes in fresh-cut Fuji apples as an alternative to the use of ascorbic acid. J. Food Sci. 73: 267-272.

[51] Sandhya 2010. Modified atmosphere packaging of fresh produce: Current status and future needs. $L W T$ Food Sci. Technol. 43: 381-392.

[52] Selmon, I. D. 1994. Vitamin retention during blanching of vegetables. Food chemistry. 49: 137-147.

[53] Serea, C., Barna, O., Manley, M. and Kidd, M. 2014. Effect of storage temperature on the ascorbic acid content, total phenolic content and antioxidant activity in lettuce (Lactuca sativa). J. Anim. Plant Sci. 24(4): 1173-1177.

[54] Serrato, L., Rincon, L. and Pineros-Castro, Y. 2014. Effect of chlorine dioxide and ozone on physiochemical, microbiological and nutritional parameters of iceberg lettuce (Lactuca sativa varcapitata) in simulated postharvest handling in the Bogota sabana, Colombia. Acta Hort. 906: 177-182.
[55] Sharma, M., Lakshman, S., Ferguson, S., Ingram, D. T., Luo, Y. and Patel, J. 2011. Effect of modified atmosphere packaging on the persistence and expression of virulence factors of Escherichia coli 0157: H7 on shredded iceberg lettuce. J. Food Prot. 74(5): 718-726.

[56] Soliva-Fortuny, R. C. and Martin-Belloso, O. 2003. New advances in extending the shelf-life of cut fruits. A review trends in Postharvest Sci. Technol. 14: 341353.

[57] Spinardi, A., Cocetta, G., Baldassarre, V., Ferrante, A. and Mignani, I. 2010. Quality changes during storage of spinach and lettuce baby leaf. Acta Hort. 877: 571576.

[58] Thompson, J. F. 2004. Precooling and storage facilities. Washington: United States Dept. of AgricultureUSDA. Agric. Handbook. No. 66.

[59] Tuncay, O. and Kusaksiz, E. 2003. Quality changes in fresh-cut leeks. Ege. Univ. Ziraat. Fak. Derg. 40(3): 41-48.

[60] Varoquaux, P. 1991. Ready to use fresh fruits and vegetables. Rev. Gen. Froid. 81: 33-43.

[61] Watada, E. and Qi, L. 1999. Quality of fresh-cut produce. Postharvest Biol. Technol. 15(3): 201-205.

Table.1: Effect of different lettuce cultivars, cut forms and storage conditions on the changes in percent moisture and physiological loss in weight (\%)

\begin{tabular}{|c|c|c|c|c|c|c|}
\hline \multirow{3}{*}{$\begin{array}{c}\text { Treatment } \\
\text { combinations }\end{array}$} & \multicolumn{3}{|c|}{ Percent moisture } & \multicolumn{3}{|c|}{ Physiological loss in weight } \\
\hline & \multicolumn{6}{|c|}{ Storage period (days) } \\
\hline & 9 & 12 & 15 & 9 & 12 & 15 \\
\hline V1 & $89.92^{\mathrm{a}}$ & $89.81^{\mathrm{a}}$ & - & $0.87^{\mathrm{d}}$ & $0.97^{\mathrm{c}}$ & - \\
\hline $\mathbf{V 2}$ & $90.12^{\mathrm{b}}$ & $90.02^{\mathrm{b}}$ & - & $0.86^{\mathrm{c}}$ & $0.95^{\mathrm{bc}}$ & - \\
\hline $\mathbf{V 3}$ & $90.65^{\mathrm{c}}$ & $90.49^{\mathrm{c}}$ & - & $0.84^{\mathrm{b}}$ & $0.93^{\mathrm{b}}$ & - \\
\hline V4 & $90.94^{\mathrm{d}}$ & $90.69^{d}$ & 90.15 & $0.78^{a}$ & $0.82^{\mathrm{a}}$ & 0.99 \\
\hline SE & 0.002 & 0.001 & & 0.0006 & 0.0006 & \\
\hline CD at $1 \%$ & 0.008 & 0.003 & & 0.0024 & 0.0023 & \\
\hline $\mathrm{T} 1$ & 90.41 & 90.25 & 90.15 & 0.84 & 0.91 & 0.99 \\
\hline T2 & - & - & - & - & - & - \\
\hline \multicolumn{7}{|l|}{ SE } \\
\hline \multicolumn{7}{|l|}{ CD at $1 \%$} \\
\hline F1 & 90.89 & 90.25 & 90.15 & 0.72 & 0.91 & 0.99 \\
\hline F2 & 89.92 & - & - & 0.96 & - & - \\
\hline SE & 0.002 & & & 0.0005 & & \\
\hline CD at $1 \%$ & 0.007 & & & 0.0021 & & \\
\hline V1T1 & 89.92 & 89.81 & - & 0.87 & 0.97 & - \\
\hline V1T2 & - & - & - & - & - & - \\
\hline V2T1 & 90.12 & 90.02 & - & 0.86 & 0.95 & - \\
\hline V2T2 & - & - & - & - & - & - \\
\hline
\end{tabular}




\begin{tabular}{|c|c|c|c|c|c|c|}
\hline V3T1 & 90.65 & 90.49 & - & 0.84 & 0.93 & - \\
\hline V3T2 & - & - & - & - & - & - \\
\hline V4T1 & 90.94 & 90.69 & 90.15 & 0.78 & 0.82 & 0.99 \\
\hline V4T2 & - & - & - & - & - & - \\
\hline SE & 0.004 & 0.001 & & 0.0011 & 0.0011 & \\
\hline CD at $1 \%$ & 0.014 & 0.005 & & 0.0041 & 0.0040 & \\
\hline V1F1 & 90.58 & 89.81 & - & 0.75 & 0.97 & - \\
\hline V1F2 & 89.25 & - & - & 0.99 & - & - \\
\hline V2F1 & 90.78 & 90.02 & - & 0.74 & 0.95 & - \\
\hline V2F2 & 89.46 & - & - & 0.98 & - & - \\
\hline V3F1 & 90.91 & 90.49 & - & 0.73 & 0.93 & - \\
\hline V3F2 & 90.39 & - & - & 0.96 & - & - \\
\hline V4F1 & 91.29 & 90.69 & 90.15 & 0.66 & 0.82 & 0.99 \\
\hline V4F2 & 90.59 & - & - & 0.90 & - & - \\
\hline SE & 0.004 & 0.001 & & 0.0011 & 0.0011 & \\
\hline CD at $1 \%$ & 0.014 & 0.005 & & 0.0041 & 0.0040 & \\
\hline T1F1 & 90.89 & 90.25 & 90.15 & 0.72 & 0.91 & 0.99 \\
\hline T1F2 & 89.92 & - & - & 0.96 & - & - \\
\hline T2F1 & - & - & - & - & - & - \\
\hline T2F2 & - & - & - & - & - & - \\
\hline SE & 0.003 & & & 0.0009 & & 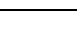 \\
\hline CD at $1 \%$ & 0.012 & & & 0.0036 & & \\
\hline V1T1F1 & 90.58 & 89.81 & - & 0.75 & 0.97 & - \\
\hline V1T1F2 & 89.25 & - & - & 0.99 & - & - \\
\hline V1T2F1 & - & - & - & - & - & - \\
\hline V1T2F2 & - & - & - & - & - & - \\
\hline V2T1F1 & 90.78 & 90.02 & - & 0.74 & 0.95 & - \\
\hline V2T1F2 & 89.46 & - & - & 0.98 & - & - \\
\hline V2T2F1 & - & - & - & - & - & - \\
\hline V2T2F2 & - & - & - & - & - & - \\
\hline V3T1F1 & 90.91 & 90.49 & - & 0.73 & 0.93 & - \\
\hline V3T1F2 & 90.39 & - & - & 0.96 & - & - \\
\hline V3T2F1 & - & - & - & - & - & - \\
\hline V3T2F2 & - & - & -- & - & - & - \\
\hline V4T1F1 & 91.29 & 90.69 & 90.15 & 0.66 & 0.82 & 0.99 \\
\hline V4T1F2 & 90.59 & - & - & 0.90 & - & - \\
\hline V4T2F1 & - & - & - & - & - & - \\
\hline V4T2F2 & - & - & - & - & - & - \\
\hline SE & 0.006 & 0.002 & & 0.0019 & 0.0018 & \\
\hline CD at $1 \%$ & 0.024 & 0.008 & & 0.0072 & 0.0070 & \\
\hline
\end{tabular}

- - indicates termination of treatments $(P \leq 0.05)$

$\mathrm{V}_{1}=\mathrm{GKL}-1$

$\mathrm{V}_{2}=\mathrm{GKL}-2$

$\mathrm{V}_{3}=\mathrm{GKL}-3$

$\mathrm{V}_{4}=$ Chinese yellow
$\mathrm{T}_{1}=$ Refrigerated storage

$\left(5 \pm 1^{\circ} \mathrm{C}\right)$

$\mathrm{T}_{2}=\mathrm{ZECC}\left(9-15^{\circ} \mathrm{C}\right)$

$\mathrm{F}_{1}=$ Whole leaf

$\mathrm{F}_{2}=$ Cut form 
Table.2: Effect of different lettuce cultivars, cut forms and storage conditions on the changes in browning and decay percentage

\begin{tabular}{|c|c|c|c|c|c|c|}
\hline \multirow{3}{*}{$\begin{array}{c}\text { Treatment } \\
\text { combinations }\end{array}$} & \multicolumn{3}{|c|}{ Browning percentage } & \multicolumn{3}{|c|}{ Decay percentage } \\
\hline & \multicolumn{6}{|c|}{$\begin{array}{l}\text { Storage period (days) } \\
\end{array}$} \\
\hline & 9 & 12 & 15 & 9 & 12 & 15 \\
\hline V1 & $4.03(0.07)^{\mathrm{d}}$ & $4.38(0.08)^{\mathrm{d}}$ & - & $2.61(0.05)^{\mathrm{d}}$ & $3.03(0.05)^{\mathrm{d}}$ & - \\
\hline $\mathbf{V 2}$ & $3.69(0.06)^{\mathrm{c}}$ & $4.02(0.07)^{\mathrm{c}}$ & - & $2.43(0.04)^{\mathrm{c}}$ & $2.84(0.05)^{\mathrm{c}}$ & - \\
\hline $\mathbf{V 3}$ & $3.51(0.06)^{\mathrm{b}}$ & $3.92(0.07)^{\mathrm{b}}$ & - & $2.20(0.04)^{\mathrm{b}}$ & $2.55(0.04)^{\mathrm{b}}$ & - \\
\hline V4 & $3.17(0.06)^{\mathrm{a}}$ & $3.79(0.07)^{\mathrm{a}}$ & $4.17(0.07)$ & $2.01(0.04)^{\mathrm{a}}$ & $2.21(0.04)^{\mathrm{a}}$ & $2.87(0.05)$ \\
\hline SE & 0.00008 & 0.00004 & & 0.00004 & 0.00003 & \\
\hline CD at $1 \%$ & 0.00029 & 0.00014 & & 0.00011 & 0.00009 & \\
\hline $\mathrm{T} 1$ & $3.60(0.06)$ & $4.03(0.07)$ & $4.17(0.07)$ & $2.31(0.04)$ & $2.65(0.05)$ & $2.87(0.05)$ \\
\hline T2 & - & - & - & - & - & - \\
\hline \multicolumn{7}{|l|}{ SE } \\
\hline \multicolumn{7}{|l|}{ CD at $1 \%$} \\
\hline F1 & $3.27(0.06)$ & $4.03(0.07)$ & $4.17(0.07)$ & $1.89(0.03)$ & $2.65(0.05)$ & $2.87(0.05)$ \\
\hline F2 & $3.93(0.07)$ & - & - & $\begin{array}{c}2.73 \\
(0.048)\end{array}$ & - & - \\
\hline SE & 0.00007 & & & 0.00003 & & 0.00011 \\
\hline CD at $1 \%$ & 0.00025 & & & 0.00009 & & 0.00044 \\
\hline V1T1 & $4.03(0.07)$ & $4.38(0.08)$ & - & $2.61(0.05)$ & $3.03(0.05)$ & - \\
\hline V1T2 & - & - & - & - & - & - \\
\hline V2T1 & $3.69(0.06)$ & $4.02(0.07)$ & - & $2.43(0.04)$ & $2.84(0.05)$ & - \\
\hline V2T2 & - & - & - & - & - & - \\
\hline V3T1 & $3.51(0.06)$ & $3.92(0.07)$ & - & $2.20(0.04)$ & $2.55(0.04)$ & - \\
\hline V3T2 & - & - & - & - & - & \\
\hline V4T1 & $3.17(0.06)$ & $3.79(0.07)$ & $4.17(0.07)$ & $2.01(0.04)$ & $2.21(0.04)$ & $2.87(0.05)$ \\
\hline V4T2 & - & - & - & - & - & - \\
\hline SE & 0.00013 & 0.00007 & & 0.00006 & 0.00005 & \\
\hline CD at $1 \%$ & 0.00051 & 0.00025 & & 0.00018 & 0.00015 & \\
\hline V1F1 & $3.72(0.06)$ & $4.38(0.08)$ & - & $2.15(0.04)$ & $3.03(0.05)$ & - \\
\hline V1F2 & $4.34(0.08)$ & - & - & $3.07(0.05)$ & - & - \\
\hline V2F1 & $3.38(0.06)$ & $4.02(0.07)$ & - & $1.93(0.03)$ & $2.84(0.05)$ & - \\
\hline V2F2 & $4.01(0.07)$ & - & - & $2.94(0.05)$ & - & - \\
\hline V3F1 & $3.20(0.06)$ & $3.92(0.07)$ & - & $1.85(0.03)$ & $2.55(0.04)$ & - \\
\hline V3F2 & $3.82(0.07)$ & - & - & $2.56(0.04)$ & - & - \\
\hline V4F1 & $2.77(0.05)$ & $3.79(0.07)$ & $4.17(0.07)$ & $1.65(0.03)$ & $2.21(0.04)$ & $2.87(0.05)$ \\
\hline V4F2 & $3.57(0.06)$ & - & - & $2.38(0.04)$ & - & - \\
\hline SE & 0.00013 & 0.00007 & & 0.00006 & 0.00005 & \\
\hline CD at $1 \%$ & 0.00051 & 0.00025 & & 0.00018 & 0.00015 & \\
\hline T1F1 & $3.27(0.06)$ & $4.03(0.07)$ & $4.17(0.07)$ & $1.89(0.03)$ & $2.65(0.05)$ & $2.87(0.05)$ \\
\hline T1F2 & $3.93(0.07)$ & - & - & $2.73(0.050$ & - & - \\
\hline T2F1 & - & - & - & - & - & - \\
\hline T2F2 & - & - & - & - & - & - \\
\hline SE & 0.00011 & & & 0.00006 & & \\
\hline CD at $1 \%$ & 0.00044 & & & 0.00016 & & \\
\hline V1T1F1 & $3.72(0.06)$ & $4.38(0.08)$ & - & $2.15(0.04)$ & $3.03(0.05)$ & - \\
\hline V1T1F2 & $4.34(0.08)$ & - & - & $3.07(0.05)$ & - & - \\
\hline
\end{tabular}




\begin{tabular}{|c|c|c|c|c|c|c|}
\hline V1T2F1 & - & - & - & - & - & - \\
\hline V1T2F2 & - & - & - & - & - & - \\
\hline V2T1F1 & $3.37(0.06)$ & $4.02(0.07)$ & - & $1.93(0.03)$ & $2.84(0.050$ & - \\
\hline V2T1F2 & $4.01(0.07)$ & - & - & $2.94(0.05)$ & - & - \\
\hline V2T2F1 & - & - & - & - & - & - \\
\hline V2T2F2 & - & - & - & - & - & - \\
\hline V3T1F1 & $3.2(0.06)$ & $3.92(0.07)$ & - & $1.85(0.030$ & $2.55(0.04)$ & - \\
\hline V3T1F2 & $3.82(0.07)$ & - & - & $2.56(0.04)$ & - & - \\
\hline V3T2F1 & - & - & - & - & - & - \\
\hline V3T2F2 & - & - & - & - & - & - \\
\hline V4T1F1 & $2.76(0.05)$ & $3.79(0.07)$ & $4.16(0.07)$ & $1.65(0.03)$ & $2.21(0.04)$ & $2.87(0.05)$ \\
\hline V4T1F2 & $3.56(0.06)$ & - & - & $2.38(0.04)$ & - & - \\
\hline V4T2F1 & - & - & - & - & - & - \\
\hline V4T2F2 & - & - & - & - & - & - \\
\hline SE at 1\% & 0.00088 & 0.00043 & & 0.00032 & 0.00026 & - \\
\hline
\end{tabular}

- - indicates termination of treatments

*Duncan's Multiple Range Test $(P \leq 0.05)$

*Figures in parenthesis indicate the corresponding arcsine value

$\mathrm{V}_{1}=\mathrm{GKL}-1$

$\mathrm{T}_{1}=$ Refrigerated storage $\left(5 \pm 1^{\circ} \mathrm{C}\right)$

$\mathrm{V}_{2}=\mathrm{GKL}-2$

$\mathrm{T}_{2}=\mathrm{ZECC}\left(9-15^{\circ} \mathrm{C}\right)$

$\mathrm{V}_{3}=\mathrm{GKL}-3$

$\mathrm{F}_{1}=$ Whole leaf

$\mathrm{V}_{4}=$ Chinese yellow

$\mathrm{F}_{2}=$ Cut form

Table.3: Effect of different lettuce cultivars, cut forms and storage conditions on the changes in ascorbic acid content and polyphenols content ( $\mathrm{mg} / \mathrm{l} 00 \mathrm{~g} \mathrm{GAE}$ )

\begin{tabular}{|c|c|c|c|c|c|c|}
\hline \multirow{3}{*}{$\begin{array}{c}\text { Treatment } \\
\text { combinations }\end{array}$} & \multicolumn{3}{|c|}{ Ascorbic acid content } & \multicolumn{3}{|c|}{ Polyphenols content } \\
\hline & \multicolumn{6}{|c|}{$\begin{array}{l}\text { Storage period (days) } \\
\end{array}$} \\
\hline & 9 & 12 & 15 & 9 & 12 & 15 \\
\hline V1 & $11.20^{\mathrm{a}}$ & $11.16^{\mathrm{a}}$ & - & $8.59^{\mathrm{a}}$ & $8.58^{\mathrm{a}}$ & - \\
\hline V2 & $11.29^{\mathrm{b}}$ & $11.24^{\mathrm{b}}$ & - & $8.61^{\mathrm{b}}$ & $8.60^{\mathrm{b}}$ & - \\
\hline V3 & $11.34^{\mathrm{c}}$ & $11.30^{\mathrm{c}}$ & - & $8.65^{\mathrm{c}}$ & $8.63^{\mathrm{c}}$ & - \\
\hline V4 & $11.41^{\mathrm{d}}$ & $11.38^{\mathrm{d}}$ & 11.24 & $8.65^{\mathrm{d}}$ & $8.64^{\mathrm{d}}$ & 8.61 \\
\hline SE & 0.001 & 0.001 & & 0.0002 & 0.0001 & \\
\hline CD at $1 \%$ & 0.004 & 0.003 & & 0.0009 & 0.0003 & \\
\hline T1 & 11.31 & 11.27 & 11.24 & 8.63 & 8.62 & 8.61 \\
\hline T2 & - & - & - & - & - & - \\
\hline \multicolumn{7}{|l|}{ SE } \\
\hline \multicolumn{7}{|l|}{ CD at $1 \%$} \\
\hline F1 & 11.34 & 11.27 & 11.24 & 8.64 & 8.62 & 8.61 \\
\hline F2 & 11.28 & - & - & 8.61 & - & - \\
\hline SE & 0.001 & & & 0.0002 & & \\
\hline CD at $1 \%$ & 0.003 & & & 0.0008 & & \\
\hline V1T1 & 11.20 & 11.16 & - & 8.59 & 8.58 & - \\
\hline V1T2 & - & - & - & - & - & - \\
\hline V2T1 & 11.29 & 11.24 & - & 8.61 & 8.60 & - \\
\hline V2T2 & - & - & - & - & - & - \\
\hline
\end{tabular}




\begin{tabular}{|c|c|c|c|c|c|c|}
\hline V3T1 & 11.34 & 11.30 & - & 8.65 & 8.63 & - \\
\hline V3T2 & - & - & - & - & - & - \\
\hline V4T1 & 11.41 & 11.38 & 11.24 & 8.65 & 8.64 & 8.61 \\
\hline V4T2 & - & - & - & - & - & - \\
\hline $\mathbf{S E}$ & 0.002 & 0.001 & & 0.0004 & 0.0001 & \\
\hline CD at $1 \%$ & 0.007 & 0.006 & . & 0.0016 & 0.0006 & \\
\hline V1F1 & 11.23 & 11.16 & - & 8.60 & 8.58 & - \\
\hline V1F2 & 11.17 & - & - & 8.58 & - & - \\
\hline V2F1 & 11.33 & 11.24 & - & 8.63 & 8.60 & - \\
\hline V2F2 & 11.26 & - & - & 8.60 & - & - \\
\hline V3F1 & 11.37 & 11.30 & - & 8.66 & 8.63 & - \\
\hline V3F2 & 11.31 & - & - & 8.64 & - & - \\
\hline V4F1 & 11.44 & 11.38 & 11.24 & 8.66 & 8.64 & 8.61 \\
\hline V4F2 & 11.38 & - & - & 8.64 & - & - \\
\hline SE & 0.002 & 0.001 & & 0.0004 & 0.0001 & \\
\hline CD at $1 \%$ & 0.007 & 0.006 & & 0.0016 & 0.0006 & \\
\hline T1F1 & 11.34 & 11.27 & 11.24 & 8.64 & 8.62 & 8.61 \\
\hline T1F2 & 11.28 & - & - & 8.61 & - & - \\
\hline T2F1 & - & - & - & - & - & - \\
\hline T2F2 & - & - & - & - & - & - \\
\hline $\mathbf{S E}$ & 0.002 & & & 0.0004 & & 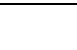 \\
\hline CD at $1 \%$ & 0.006 & & 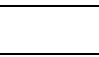 & 0.0014 & & \\
\hline V1T1F1 & 11.23 & 11.16 & - & 8.60 & 8.58 & - \\
\hline V1T1F2 & 11.17 & - & - & 8.58 & - & - \\
\hline V1T2F1 & - & - & - & - & - & - \\
\hline V1T2F2 & - & - & - & - & - & - \\
\hline V2T1F1 & 11.33 & 11.24 & - & 8.63 & 8.60 & - \\
\hline V2T1F2 & 11.26 & - & - & 8.60 & - & - \\
\hline V2T2F1 & - & - & - & - & - & - \\
\hline V2T2F2 & - & - & - & - & - & - \\
\hline V3T1F1 & 11.37 & 11.30 & - & 8.66 & 8.63 & - \\
\hline V3T1F2 & 11.31 & - & - & 8.64 & - & - \\
\hline V3T2F1 & - & - & - & - & - & - \\
\hline V3T2F2 & - & - & - & - & - & - \\
\hline V4T1F1 & 11.44 & 11.38 & 11.24 & 8.66 & 8.64 & 8.61 \\
\hline V4T1F2 & 11.38 & - & - & 8.64 & - & - \\
\hline V4T2F1 & - & - & - & - & - & - \\
\hline V4T2F2 & - & - & - & - & - & - \\
\hline SE & 0.003 & 0.003 & & 0.0007 & 0.0003 & \\
\hline CD at $1 \%$ & 0.012 & 0.010 & & 0.0028 & 0.0010 & \\
\hline
\end{tabular}

- - indicates termination of treatments $(P \leq 0.05)$

$\mathrm{V}_{1}=\mathrm{GKL}-1$

$\mathrm{V}_{2}=\mathrm{GKL}-2$

$\mathrm{V}_{3}=\mathrm{GKL}-3$

$\mathrm{V}_{4}=$ Chinese yellow
$\mathrm{T}_{1}=$ Refrigerated storage $\left(5 \pm 1^{\circ} \mathrm{C}\right)$

$\mathrm{T}_{2}=\mathrm{ZECC}\left(9-15^{\circ} \mathrm{C}\right)$

$F_{1}=$ Whole leaf

$\mathrm{F}_{2}=$ Cut form 


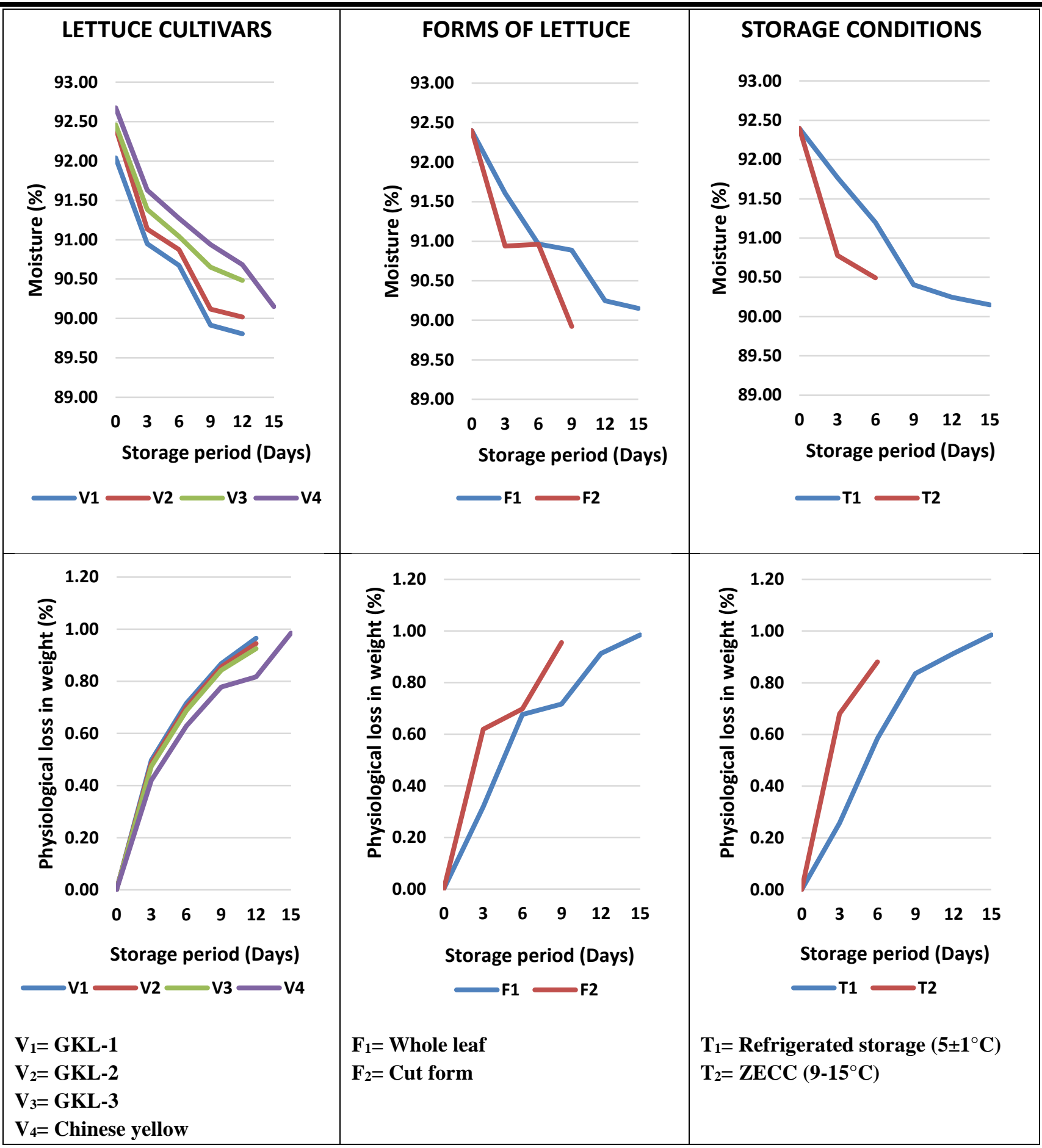

Fig.1: Effect of different lettuce cultivars, cut forms and storage conditions on percent moisture and physiological loss in weight 


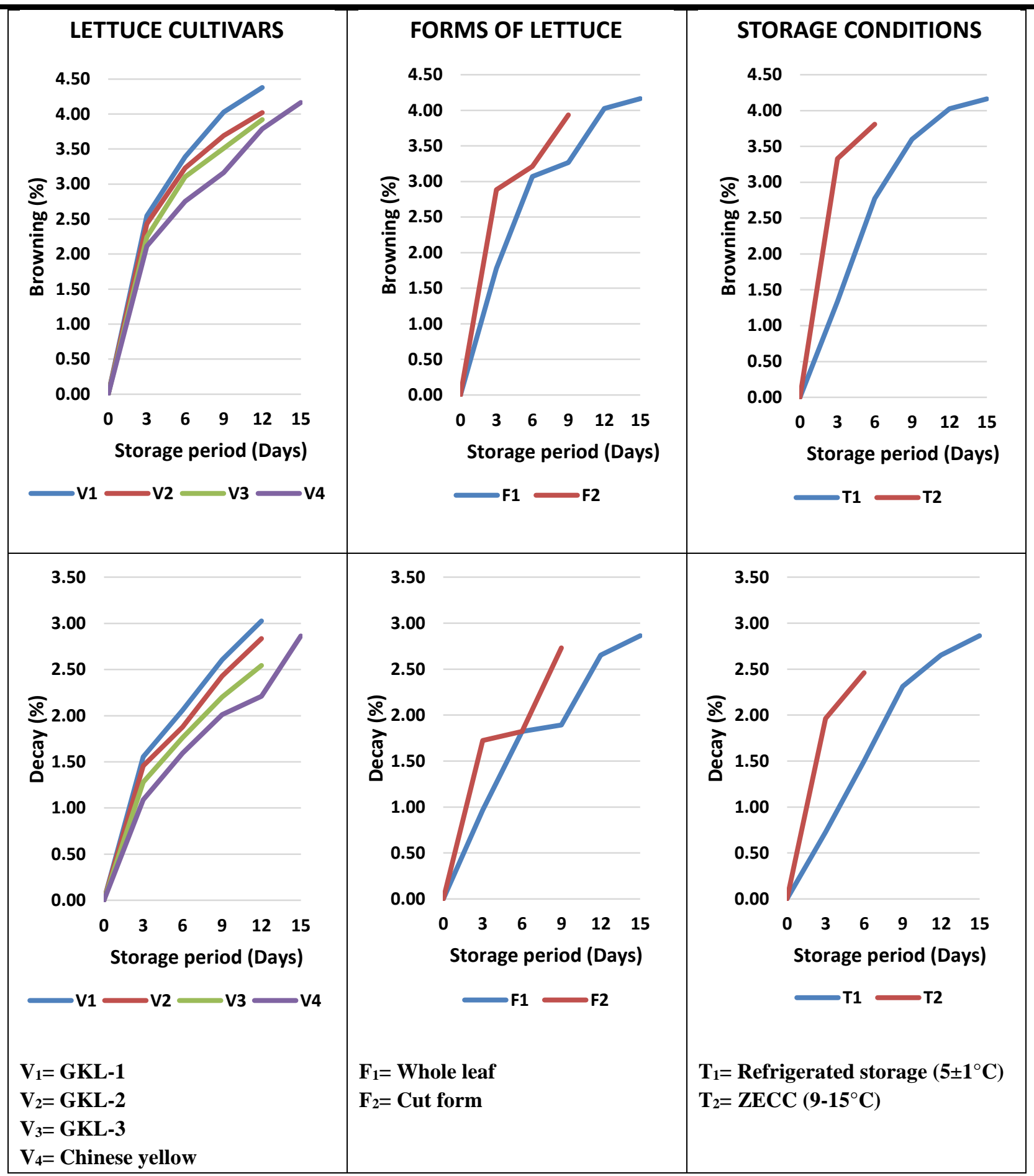

Fig.2: Effect of different lettuce cultivars, cut forms and storage conditions on browning and decay percentage 


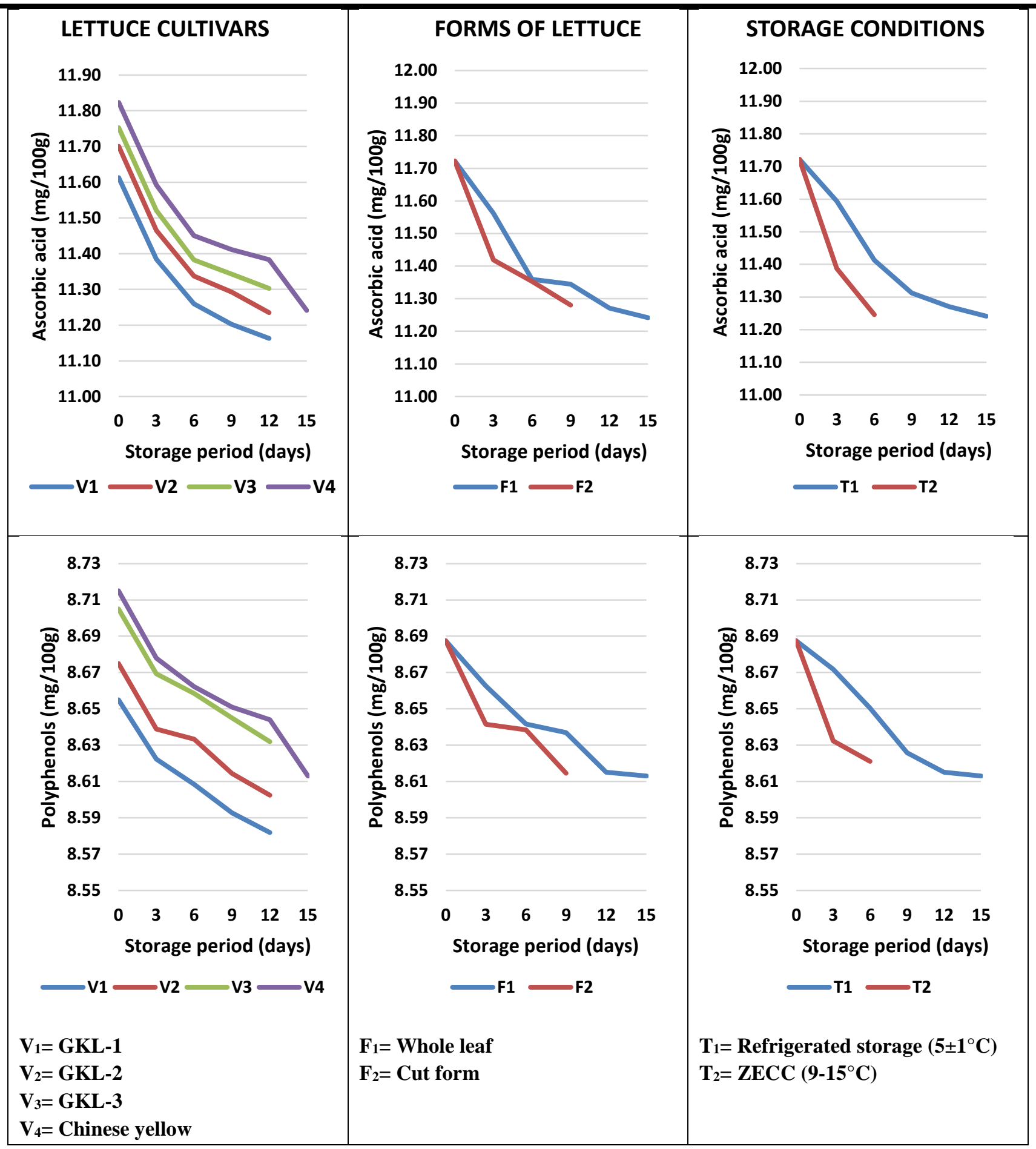

Fig.3: Effect of different lettuce cultivars, cut forms and storage conditions on ascorbic acid and polyphenols content 